\title{
Artisanal fisheries in the conservation zones of the Upper Gulf of California
}

\author{
Pesca artesanal en las zonas de conservación del Alto Golfo de California \\ Gerardo Rodríguez-Quiroz ${ }^{1}$, E. Alberto Aragón-Noriega ${ }^{2}$, Wenceslao \\ Valenzuela-Quiñónez ${ }^{1}$ and Héctor M. Esparza-Leal ${ }^{1}$ \\ ${ }^{1}$ Centro Interdisciplinario de Investigación para el Desarrollo Integral Regional, Unidad Sinaloa. \\ Blvd. Juan de Dios Bátiz Paredes 250, Guasave, Sinaloa 81101, México \\ ${ }^{2}$ Centro de Investigaciones Biológicas del Noroeste, Unidad Sonora. Km 2.35 Camino al Tular, \\ Estero de Bacochibampo, Guaymas, Sonora 85454, México
}

grquiroz@ipn.mx

\begin{abstract}
Resumen.- A nivel mundial las áreas marinas protegidas (AMP) son usadas como herramientas para proteger ecosistemas. Existe un debate sobre si las áreas marinas deben ser usadas para proteger e incrementar la biodiversidad ó como una herramienta de manejo pesquero, ó bien con ambos propósitos. Los estudios científicos contribuyen para demostrar los efectos de estas áreas sobre las zonas de pesca. El Alto Golfo de California (AGC) es una región pesquera altamente explotada por los pescadores artesanales de tres comunidades: San Felipe en Baja California, El Golfo de Santa Clara y Puerto Peñasco en Sonora, encontrándose dos áreas marinas protegidas. Se evalúa si con esta herramienta de manejo se ha beneficiado a los pescadores de esta región, como las áreas de la pesca artesanal para tener un diagnóstico de las AMP. La pesca artesanal aumenta conforme se incrementa el número de embarcaciones, pero no así la captura por unidad de esfuerzo que es de 10 ton embarcación ${ }^{-1}$ año $^{-1}$. A través de un sistema de información geográfica realizado ex profeso se identificó que el 62\% de la pesca se realiza en dos áreas marinas protegidas del AGC y la captura genera aproximadamente US\$ 5,897 millones al año, con una tasa de retorno de $\sim 68 \%$. Aunque el esfuerzo pesquero ha aumentado, los márgenes de ganancia se han mantenido. La explotación pesquera en las AMP deben tener un seguimiento interdisciplinario y complejo debido a la presencia de especies en peligro de extinción en la región, en la que se debe fomentar prácticas de manejo apropiadas con la finalidad de conservar el medio marino sin comprometer los intereses individuales de los pescadores.
\end{abstract}

Palabras clave: Áreas marinas protegidas, pesquería sustentable, ingresos, pescadores, conservación

\section{Introduction}

Mexico has an important tradition of small-scale artisanal fisheries. The Gulf of California is one of the major areas of operation for these small fisheries. Fisheries in this area catch $20 \%$ of the national fish production, and over 50,000 small-scale vessels exploit the local resources

\begin{abstract}
Marine protected areas (MPAs) are increasingly being used as management tools to protect ecosystems around the world, but there is some debate as to whether marine protected areas should be used as a tool to protect and increase biodiversity, as a fisheries management tool or as a tool that serves both purposes. Scientific studies help to demonstrate the effects of these areas on adjacent fishing grounds. The Upper Gulf of California (UGC) is one of the most important fishing regions exploited by artisanal fishermen. There are three neighboring communities in the area: San Felipe in Baja California and Golfo de Santa Clara and Puerto Peñasco in Sonora. These areas are adjacent to two MPAs. We assessed whether the MPAs in the area have promoted the welfare of the fisherman, and we tried to identify the important grounds for artisanal fishing in an effort to improve the designation of MPAs. Capture increased as fishermen incorporated more boats into their fleets, but the total capture per unit, which is about 10 ton boat $^{-1}$ year $^{-1}$, decreased. A Geographical Information System survey indicated that $62 \%$ of all artisanal fishing was occurring within the MPAs of the UGC. This fishing generated gross profits of approximately US\$ 5,897 million per year, with return rates of $68 \%$. Even with an increased fishing effort, gross profit margins have been sustained. The fishermen's exploitation of the MPAs needs to undergo a complex interdisciplinary evaluation because of the presence of endangered species in the region. Appropriate management practices are needed to enhance marine conservation efforts without compromising the interests of local fishermen.
\end{abstract}

Key words: Marine protected areas, sustainable fishery, gross profit, fishermen, conservation

(Cisneros 2001, SAGARPA 2002). The gulf is divided into four regions based on biological, ecological and oceanographic characteristics. One of these regions is the Upper Gulf of California (UGC), which is of great importance for pelagic species and estuarine-dependent species (Galindo et al. 2000, Ramírez \& Aragón 2006). 
Due to the high temperatures and lack of freshwater along the UGC coast, the most important economic activities in the region are fisheries and tourism (Godinez 1993). The two types of commercial fishing taking place in the UGC are artisanal (small scale) and industrial fishing. Artisanal fishing is carried out by organizations called cooperatives and by individual fishers from the three ports of the UGC (Puerto Peñasco and El Golfo de Santa Clara in the State of Sonora and San Felipe in the State of Baja California, Cudney \& Turk 1998).

The UGC and the Colorado River Delta region were declared a Biosphere Reserve on June 10, 1993. This reserve has an area of 934,756 ha and it includes marine and terrestrial environments ${ }^{1}$ (Fig. 1). This Reserve was created to protect species that are commercially important, endemic or at risk of extinction (Cudney \& Turk 1998).
The area is currently supported by a management program designed to promote sustainable activities through the durable and conservation-minded use of biodiversity (SEMARNAT 1995, Rojas et al. 2006).

In the reserve, there are many species with high commercial value. Based on catch volumes and beach economic values, the six artisanal fisheries of the most importance in the UGC are blue shrimp (Litopenaeus stylirostris Stimpson, 1871), gulf curvina (Cynoscion othonopterus Jordan \& Gilbert, 1882), chano (Micropogonias megalops Gilbert, 1890), Spanish mackerel Scomberomorus spp., and several species of rays and sharks. Gulf corvine and blue shrimp are very expensive and in high demand in local and national markets $^{2}$ (Table 1).

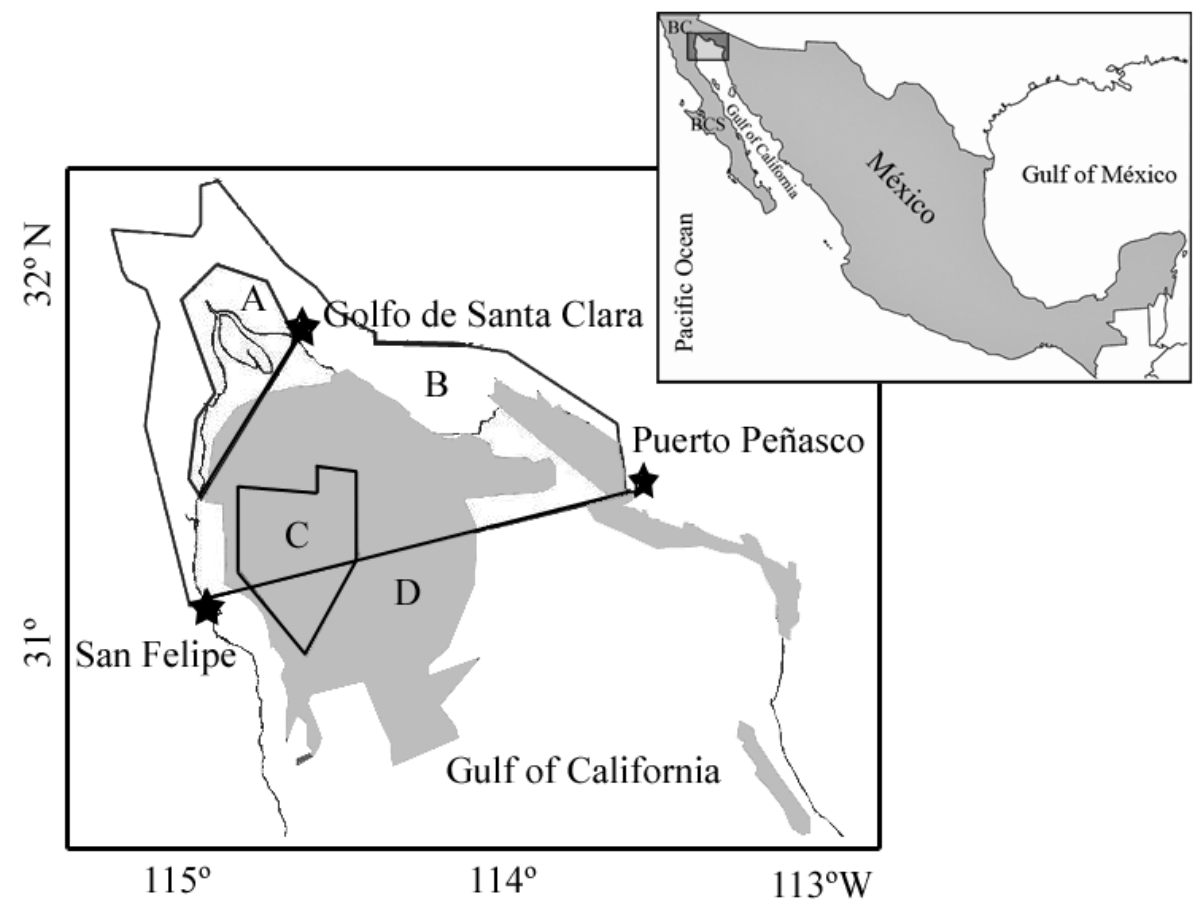

Figure 1

Spatial distribution of the artisanal fishery within the Biosphere Reserve of the Upper Gulf of California (June 1993) and Vaquita Refuge Area (December 2005). A) Nucleus Zone, B) Buffer Zone, C) Vaquita Refuge Area, D) Shadows represent fishing areas

Distribución espacial de la pesca artesanal dentro de la Reserva de la Biósfera del Alto Golfo de California (junio 1993) y del Área de Refugio de la Vaquita (Diciembre 2005). A) Área Núcleo, B) Zona de Amortiguamiento, C) Área de Refugio de la Vaquita, D) Las sombras representan áreas de pesca

${ }^{1}$ DOF. 1993. Decreto por el que se declara área natural protegida con el carácter de Reserva de la Biosfera, la región conocida como Alto Golfo de California y Delta del Río Colorado. Diario Oficial de la Federación, 10 pp. Secretaría de Gobernación, México, DF. ${ }^{2}$ Source: Federal fish government offices in the communities of the Upper Gulf of California. 
Table 1

\section{Catch (kg) and value (US\$) average of the main species in artisanal fisheries landed in the three ports of the Upper Gulf of California from 1995 to 2007}

Promedio de la captura (kg) y valor (US\$) de las principales especies desembarcadas de la pesca artesanal en los tres puertos del Alto Golfo de California de 1995 al 2007

\begin{tabular}{|c|c|c|c|c|c|c|}
\hline \multirow[t]{2}{*}{ Species } & \multicolumn{2}{|c|}{ El Golfo de Santa Clara } & \multicolumn{2}{|c|}{ San Felipe } & \multicolumn{2}{|c|}{ Puerto Peñasco } \\
\hline & Catch & Value & Catch & Value & Catch & Value \\
\hline Curvina & 2’099,595 & $2 ’ 318,303$ & 38,257 & 33,794 & 10,604 & 13,877 \\
\hline Spanish mackerel & 405,403 & 517,744 & 25,292 & 33,512 & 29,120 & 41,713 \\
\hline Big Eye Croacker & 208,174 & 469,498 & 181,253 & 355,792 & 35,565 & 94,246 \\
\hline Shrimp & 295,038 & 3'064.498 & 199,311 & $2^{\prime} 036,367$ & 53,721 & 581,261 \\
\hline Rays & 49,831 & 53,354 & 43,136 & 49,748 & 100,559 & 112,203 \\
\hline Sharks & 0 & 0 & 26,620 & 35,661 & 0 & 0 \\
\hline
\end{tabular}

Source: Federal fish government offices in the communities of the Upper Gulf of California

The potential profits from these important species have motivated fishermen to increase their fishing effort. These actions are jeopardizing critical species, such as the totoaba (Totoaba macdonaldi Gilbert, 1890) and the Vaquita (Phocoena sinus Norris \& McFarlan, 1958), which are rare and endemic species from the northern part of the Gulf of California (Hanski 1998).

Marine and coastal protected areas implemented as part of a wider marine and coastal management framework are an essential tool for the conservation and sustainable use of marine and coastal biodiversity. The marine and coastal protected areas have been shown to contribute to the protection of biodiversity and the sustainable use of biodiversity. These areas also facilitate conflict management, enhance economic well-being and improve the quality of life. Globally, marine protected areas are increasingly being used as a management tool to protect ecosystems, but there is some debate as to whether marine protected areas should also be used as a tool to protect and increase biodiversity, as a fisheries management tool or as a tool that can serve both purposes.

The benefit of marine reserves for fisheries is especially hard to define if the distribution of commercial species is not known, as is the case for the MPAs in the UGC. These MPAs were established to protect species at risk of extinction, but there is a lack of knowledge about the grounds of commercial species in the area.

In this study, we propose to identify and compute the state of these artisanal fisheries and their economic value in the UGC (considering the three fishing localities mentioned above) as a first step towards implementing a conservation plan aimed at reducing artisanal fishing in the marine protected areas (Cisneros et al. 1995, D’Agrosa et al. 1995). Although the zone was declared a Biosphere Reserve in 1993, no management measures have been taken up to this point. An analysis of the current situation and proposition of a plan to protect the endangered species in the UGC is currently needed. We analyzed the current state of the fisheries in the UGC using primary (interviews) and secondary (official catch reports) data. The basic variables, such as general Catch per Unit Effort (CPUE), effort, and catch fluctuations, are described and the fishing ground for each community was identified. Finally, the relative sustainability of each fishery was assessed using a sustainability index.

\section{Material and methods}

A total of 2,554 artisanal fishing catch reports were compiled and analyzed based on official records from 1995 to 2005 for San Felipe, Golfo de Santa Clara and Puerto Peñasco. Further information was gathered from a survey based on interviews of 146 artisanal fishers from those three ports. Questionnaires were designed to compute the direct costs of fishing operations as well as the impact of these operations on fishing sites. Following Cochran's method (1989), we obtained a value for the number of fishermen to interview, as follows:

$$
\mathrm{n}=\frac{\frac{Z^{2} q}{E^{2} p}}{1+\frac{1}{N}\left[\frac{Z^{2} q-1}{E^{2} p}\right]}
$$


where: $\mathrm{n}=$ sample size; $\mathrm{Z}=\mathrm{CI}=95 \% ; \mathrm{p}$ and $\mathrm{q}=0.5$ equation distribution; $\mathrm{E}=6 \%$ precision level; $\mathrm{N}=$ Fishermen community size. Based on the method of Greenberg (1993), local fishermen at each port were randomly selected.

To estimate a gross income (disregarding investment costs) for each community, information pertaining to capture site, weight of landings and landed price was obtained from catch records declared by fishermen at the federal government fishery offices in the studied communities.

The assessment of growing and declining periods for capture tendency of the fisheries in the UGC was measured through the Sustainable Fishery Index as detailed in Ponce et al. (2006):

$$
\mathrm{SFI}=\operatorname{Ln}\left(\mathrm{C}_{X i} / \mathrm{C}_{\text {Xmean }}\right) \text {, }
$$

where: $\mathrm{C}_{X i}=$ Capture in the present year, $\mathrm{C}_{X \text { mean }}=$ Capture mean through the entire study period.

The catch was processed and spatially represented in a Geographical Information System that identified fishing sites within the Biosphere Reserve and Vaquita Refuge (Fig. 1).The overlapping area was calculated through the use of ArcView 3.2 software and downloaded to totalfishery and by-community maps using a 2002 Conica Lambert projection. Fishing percentages within the Biosphere Reserve and Vaquita Refuge Area were obtained from the overall projected fishing sites.

\section{Results}

\section{Fishery analysis}

There are 2,100 small boats working in the Upper Gulf of California. The bulk of the fishermen use gillnets to catch curvina (100\%), shrimp (93\%), Spanish mackerel (68\%), bigeye croaker and rays (44\%) and sharks (10\%). These nets cover a great proportion of the water column and are left in the water for hours at a time. The length of these nets varies from 99 to $1,485 \mathrm{~m}$. The most used nets measure between 594 to $990 \mathrm{~m}$ long with a mean height of 5.4 to $18 \mathrm{~m}$.

The greatest number of authorized small boats was registered in Golfo de Santa Clara followed by San Felipe and then Puerto Peñasco. These numbers have changed since 1995, when Puerto Peñasco had the largest number of small boats. Over the next two years, many small boats were authorized to join the fleet. In 1997, Golfo de Santa Clara and Puerto Peñasco, both in the state of Sonora, were authorized to increase their fleets by $41 \%$ and $98 \%$, respectively. San Felipe, in the state of Baja California, had a fleet increase of almost $1000 \%$ during the same

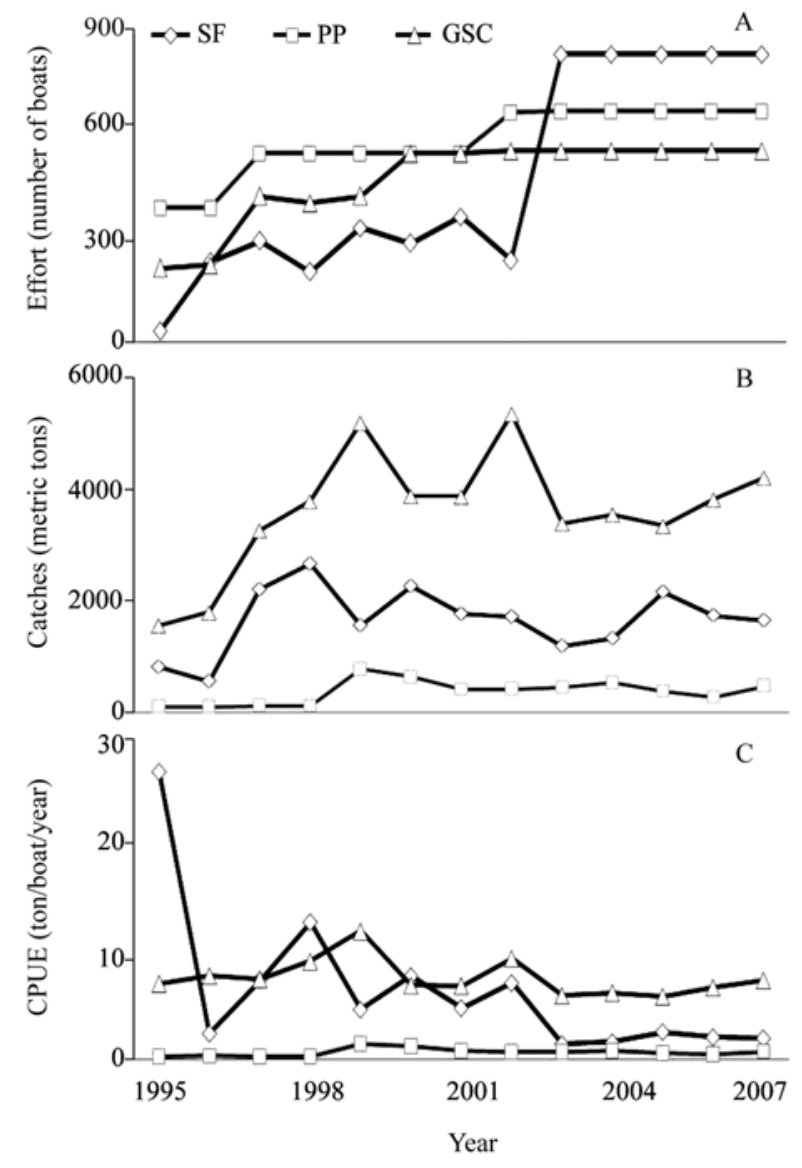

Figure 2

\section{A) Tendency of effort, B) UGC capture, C) CPUE, in the three communities of the UGC. SF) San Felipe; GSC) Golfo de Santa Clara; PP) Puerto Peñasco}

A) tendencia del esfuerzo; B) captura en el UGC; C) CPUE, en las tres comunidades del AGC. SF) San Felipe; GSC) Golfo de Santa Clara; PP) Puerto Peñasco

period. The next major increase in fleet size took place between 2001 and 2003, when the number of small boats rose to 673 in Puerto Peñasco, 557 in Golfo de Santa Clara and 840 in San Felipe. These numbers remained the same until 2007 (Fig. 2A).

The increased number of catches from 1995 to 1997 correlates with the fishing effort, as seen in San Felipe, where production tripled during this time, and Golfo de Santa Clara, where production doubled during this time. Overall, the catch weight over the thirteen-year period increased. The largest catches for San Felipe ( 2669 metric tons), Puerto Peñasco ( 748 metric tons) and Golfo de Santa Clara ( $\sim 5347$ metric tons) were observed in 1998, 1999 and 2002, respectively. It is important to 
note that the majority of the catches were by fishermen from Golfo de Santa Clara (Fig. 2B).

Since an increased effort also resulted in increased catches, the CPUE exhibited the same trend as the catches, holding Golfo de Santa Clara as the most important community with the highest production over the course of this study. It is important to mention that only Golfo de Santa Clara averaged more than 8 metric ton boat ${ }^{-1}$ year $^{-1}$ over the course of the study, higher than the other two communities' average production. Other exceptional catch averages were in San Felipe in 1995 and 1998 with 27.3 and 13.0 metric tons boat ${ }^{-1}$ year $^{-1}$, respectively (Fig. 2C).

After totaling the three communities' catches and efforts, we analyzed the total fishery to understand its total impact on the Upper Gulf of California. The effort of small boats doubled from 1995 to 1997, increasing from 635 to 1269 boats. The number of boats experienced a moderate increase from 1998 to 2002. In 2003, more fishing permits were authorized due to the growth of the corvine fisher, which increased the total number of boats to 2070. The number of small boats has remained constant since then.

Total catches and CPUE exhibited comparable profiles. For total catches, there were important peaks in 1999 (7536 metric tons) and 2002 (7492 metric tons). Total annual production in the UGC has been $\sim 6000$ tons since 2000. The CPUE showed a similar behavior although during the first year of the Biosphere Reserve, individual boat production was over 34 ton boat ${ }^{-1}$ year $^{-1}$ as a result of the reduced number of boats. During the following years, the CPUE showed considerable reductions, but it was above average (14.89 metric ton boat $^{-1}$ year $^{-1}$ ) in 1998, 1999 and 2002 with CPUE values of 22.5, 18.3 and 17.4 metric tons/boat/year, respectively.

The sustainable fishing index calculated for the three communities showed that the fishery had three periods of capture intensity ${ }^{3}$ (Fig. 3). The initial period had a lower capture rate with respect to the historical mean (5651.32 \pm 1530.89 metric tons ${ }^{-1}$ year $^{-1}$ ) due to the reduced number of small boats before 1999. The second period corresponded to the expansion of fleets and led to higher capture levels from 1998 to 2002. The next year (i.e. 2003), capture levels declined due to overexploitation tied to the increase in fleet size. The final period $\left(\sim 5866.60 \pm 329.52\right.$ metric tons year $\left.{ }^{-1}\right)$ began in 2004 after a substantial recuperation of the fishery. Some fish seasons and capture areas were extended as a result of this recuperation.

35ource: Federal Fishing Offices of the three fishing communities in the Upper Gulf of California.

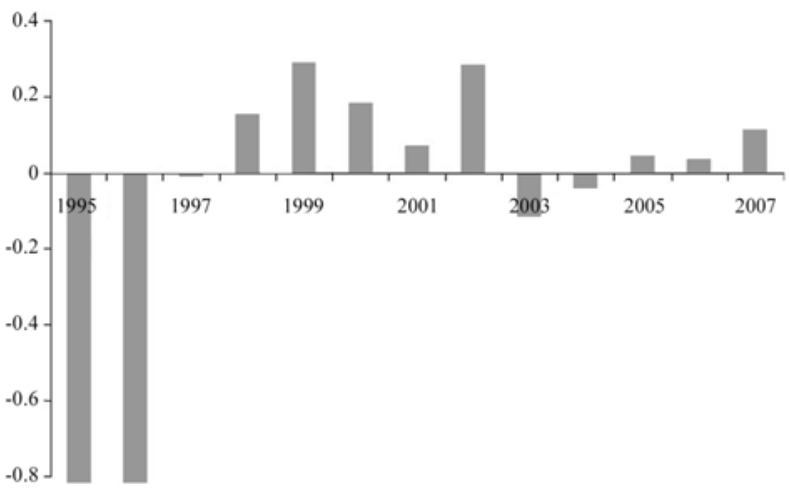

Figure 3

Sustainable fishing index of the capture in the Upper Gulf of California during the period of 1995 to 2007. Source: Federal Fishing Offices of the three fishing communities

Índice de sustentabilidad pesquera de la captura en el Alto Golfo de California durante el periodo de 1995 al 2007.

Fuente: Oficinas Federales de Pesca en las tres comunidades pesqueras

\section{GIS Interpretation}

Our survey data and GIS analysis showed that fishing is conducted within the Vaquita Refuge Area and in the Biosphere Reserve. Approximately $62 \%$ of the total catch in the Upper Gulf of California was caught in the marine protected areas. Approximately $77 \%$ of the marine area of the Biosphere Reserve and the entire Vaquita Refuge Area are used for fishing (Fig. 1).

In the Vaquita Refuge, $97 \%$ of the total area is fished for shrimp, $94 \%$ is fished for corvine, $85 \%$ is fished for shark, $79 \%$ is fished for bigeye croaker and $69 \%$ is fished for Spanish mackerel. In the Biosphere Reserve, 56\% of the total area is fished for shrimp, 55\% is fished for corvine, $44 \%$ is fished for bigeye croaker, 39\% is fished for shark and 30\% is fished for Spanish mackerel (Fig. 4).

Fishermen from Puerto Peñasco fish close to the Sonoran shoreline. Seventy-five percent of the capture occurs inside the Biosphere Reserve and the fishermen fish in $20 \%$ of the northern area of the Vaquita Refuge. Fishermen from Golfo de Santa Clara carry out their fishing inside the marine protected areas and they fish in about half of the Vaquita Refuge Area. San Felipe fishermen fish near the Baja California shoreline in the UGC from the core zone to Puertecitos, which covers the entire Vaquita Refuge Area and $70 \%$ of the Biosphere Reserve (Fig. 5). 

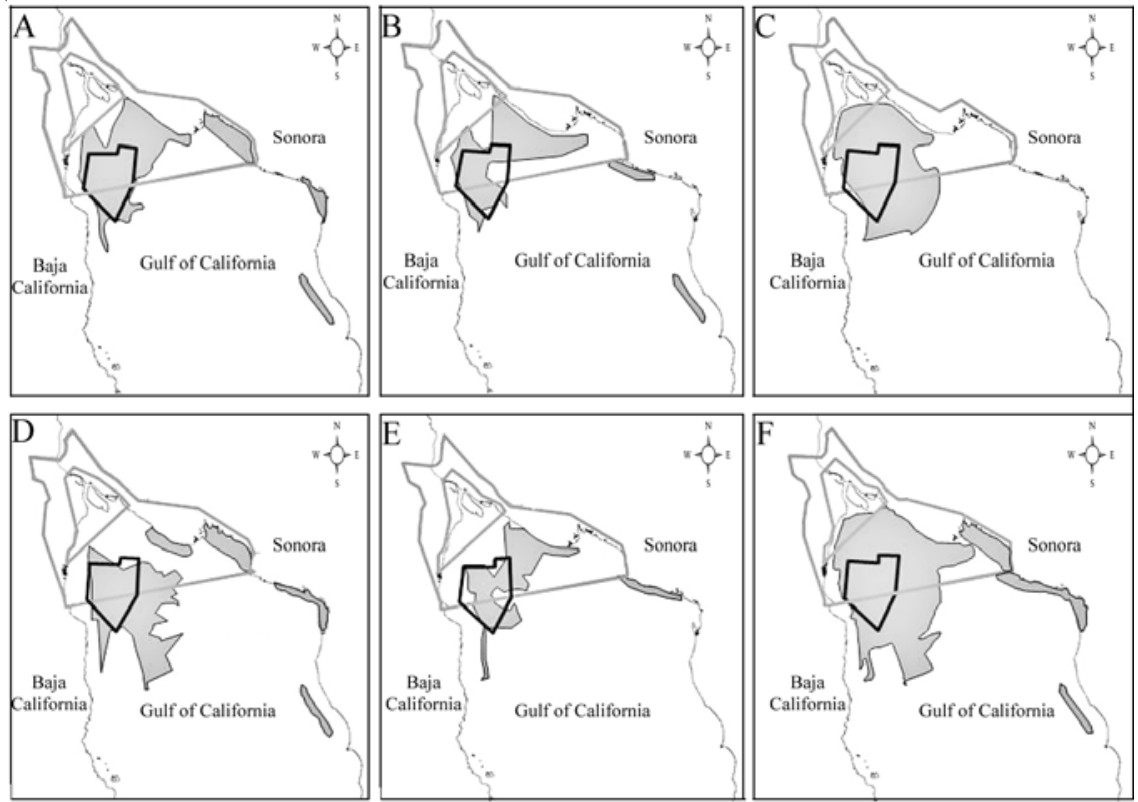

Figure 4

Spatial distribution of the artisanal fisheries in the Upper Gulf of California by species. A) Shrimp, B) Bigeye croaker, C) Curvina, D) Sharks and rays, E) Spanish mackerel, F) All fisheries

Distribución especial de la pesca artesanal en el Alto Golfo de California por especie. A) Camarón, B) Chano,

C) Corvina, D) Tiburones y rayas, E) Sierra, F) Todas las pesquerías

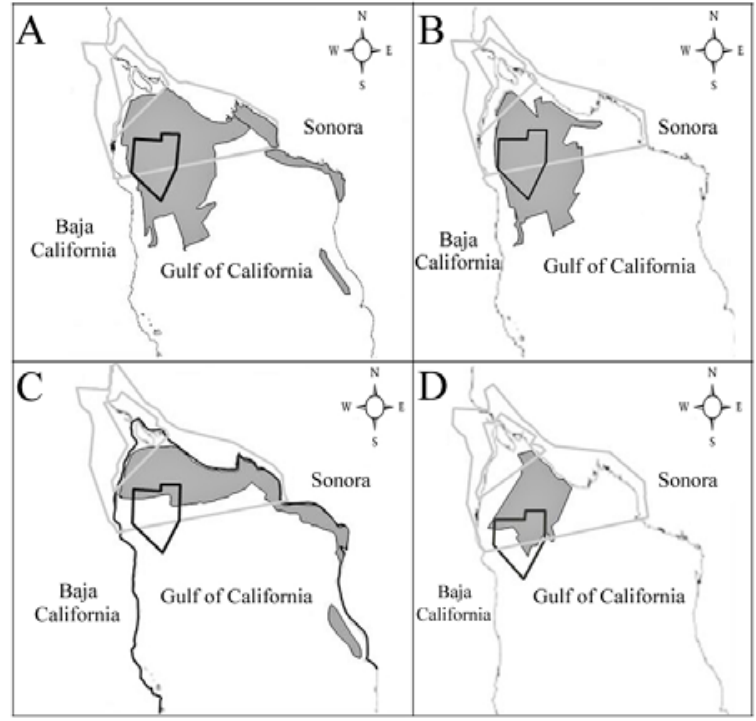

Figure 5

Spatial distribution of the artisanal fisheries in the Upper Gulf of California by community. A) All communities, B) San Felipe, C) Puerto Peñasco, D) Golfo de Santa Clara

Distribución espacial de la pesca artesanal en el Alto Golfo de California, por comunidad. A) Todas las comunidades, B) San Felipe, C) Puerto Peñasco, D) Golfo de Santa Clara 


\section{Economic value of fisheries}

The economic value of the fishery from 1995 to 2007 is shown in Table $2^{4}$. The volume of the capture for this period was $\sim 5,506$ metric tons of products with a catch value of $\sim$ US\$ 8,563 million. Operational costs for the artisanal fishery were relatively high even though the travel distance from the three ports to the fishing sites is short. Capture from the marine protected areas generates an annual profit of $\sim$ US\$ 5,897 million with a return rate of approximately 68\%. Even with increased fishing effort, gross profits provided high incomes.

\section{Social analysis}

Fishermen exploiting the marine area were asked about alternative options for employment and how they would like to be assisted by governmental authorities. If forced to change profession, $45.3 \%$ of the fishermen would turn to ecotourism and storekeeping, $8.7 \%$ would prefer to work in aquaculture and maquilas, $21.7 \%$ to another type of fishery (mollusk, clams, and oysters) or continuation in the same fishery and $17.1 \%$ would seek another type of artisan employment (Table 3).

In Puerto Peñasco and San Felipe, a large number of fishermen would seek employment in the tourism sector and over $10 \%$ would continue other fishing activities. In San Felipe and Golfo de Santa Clara, more than 20\% would seek employment as storekeepers and more than $15 \%$ would carry on fishing the same species that they currently capture. In Puerto Peñasco and Golfo de Santa Clara, fewer than $8 \%$ would seek employment in the aquaculture sector. No one would consider this option in San Felipe. About 25\% of fishermen in Golfo de Santa Clara and more than $10 \%$ of fishermen in Puerto Peñasco and San Felipe would seek employment in the construction trade.

Table 2

Catch, first-hand value product and operation costs in the artisanal fishery of the Upper Gulf of California inside the Vaquita Refuge Area and the Biosphere Reserve from 1995 to 2007

Captura, valor del producto desembarcado y costos de operación de la pesquería artesanal en el Alto Golfo de California dentro del Área de Refugio de la Vaquita y de la Reserva de la Biósfera de 1995 al 2007

\begin{tabular}{rcccccccccccccc}
\hline & 1995 & 1996 & 1997 & 1998 & 1999 & 2000 & 2001 & 2002 & 2003 & 2004 & 2005 & 2006 & 2007 & Average \\
\hline Catch (metric tons) $^{2}$ & 2510 & 2354 & 5466 & 6450 & 7536 & 6786 & 6050 & 7492 & 5029 & 5407 & 5888 & 4525 & 6087 & 5506 \\
Value of catch $^{1}$ & 3444 & 2323 & 4327 & 9451 & 9625 & 9907 & 9181 & 12882 & 8755 & 8082 & 12660 & 10356 & 10319 & 8563 \\
Costs of catch $^{1}$ & 569 & 1185 & 1640 & 1945 & 2390 & 2726 & 2994 & 3131 & 3321 & 3493 & 3609 & 3755 & 3897 & 2666 \\
Gross profit $^{1}$ & 2874 & 1138 & 2688 & 7505 & 7234 & 7181 & 6186 & 9750 & 5435 & 4589 & 9051 & 6601 & 6423 & 5897 \\
Return rate (\%) & 83 & 49 & 62 & 79 & 75 & 72 & 67 & 76 & 62 & 57 & 71 & 64 & 62 & 68 \\
\hline
\end{tabular}

1) Millions of US dollars

Table 3

Alternative employment considered by fishermen of the Marine Protected Areas

\begin{tabular}{lccrr} 
Empleos alternativos considerados por los pescadores de las Áreas Naturales Protegidas \\
\hline \multicolumn{1}{c}{ Options } & Puerto Peñasco & Golfo de Santa Clara & San Felipe & Total \\
\hline Tourism & 28.6 & 16.7 & 28.9 & 24.7 \\
Aquaculture & 7.1 & 3.3 & 0.0 & 3.5 \\
Continue fishing & 3.6 & 16.7 & 18.1 & 12.8 \\
Another fishing activity & 14.3 & 1.7 & 10.8 & 8.9 \\
Work in private sector & 3.6 & 8.3 & 3.6 & 5.2 \\
Storekeeper & 7.1 & 26.7 & 21.7 & 18.5 \\
Other (Trade) & 14.3 & 24.9 & 12.0 & 17.1 \\
Do not answer & 21.4 & 1.7 & 4.8 & 9.3 \\
\hline
\end{tabular}

\footnotetext{
${ }^{4}$ Source: Federal fish offices in the communities of the Upper Gulf of California.
} 


\section{Discussion}

This analysis showed that both the Upper Gulf of California Biosphere Reserve and the recently declared Vaquita Refuge are important grounds for artisanal fishing. Shrimp generate the greatest income for artisanal fishermen. Our survey data indicate that $98 \%$ of artisanal fishermen from El Golfo de Santa Clara and 100\% from San Felipe fish for shrimp due to its high commercial value, gross revenues and availability during the fishing season (September to January). These results are a major challenge to the goals of the Reserve and the Vaquita Refuge. This challenge is made more difficult due to the fact that the number of registered small boats is greater than the number recommended at the declaration of the Vaquita Refuge (DOF. 2005) ${ }^{5}$.

The high number of small boats working in the Upper Gulf of California represents a clear threat to the Vaquita Refuge (Rojas \& Jaramillo 2001, Blanco 2002). The bulk of artisanal fisheries use big mesh gillnets that jeopardize threatened species in the refuge. These gillnets cover a great portion of the water column and they can be left out for hours at a time (Turk-Boyer 1989, D’Agrosa et al. 1995, Walsh 2004).

Another important issue for endangered species in the fisheries is the lack of habitat. Brusca (2004) pointed out that one of the greatest threats to biodiversity in the UGC is the disruption of the Colorado River that once flowed into the UGC. This issue is heavily influenced by economic and environmental pressure from the United States. This threat has been demonstrated for shrimp (Pérez-Arvizu et al. 2009) and Gulf Corvina (Rowell et al. 2005) as well as for the endangered totoaba (Rowell et al. 2008).

Our contribution is significant because we now have more information about the habitat utilized by commercially important species. We have also collected information that can be used to elucidate which fisheries represent more of a risk to endangered species. All fisheries are not necessarily a threat to biodiversity. A better understanding of the fisheries can help us determine which fisheries are the most important to consider when developing a conservation strategy.

Once again, we emphasize the importance of habitat utilization in conservation programs. As Alfonso et al. (2009) pointed out, 'to protect essential habitats is the alternative to achieve benefices from marine reserve'.

\footnotetext{
${ }^{5}$ DOF. 2005. Programa de protección de la Vaquita dentro de área de Refugio ubicada en la porción occidental del Alto Golfo de California. Diario Oficial de la Federación, pp. 19-24. Secretaría de Gobernación, México.
}

The existence of marine reserves is no guarantee of conservation. With the findings of this study, we now know more about the habitat utilized by the commercially important species.

To a great extent, operational costs determine where fishing is conducted in the UGC. The distance of fishing sites from the ports and the seasonal distribution of resources have a great impact on operational costs. San Felipe is the fishing port closest to the Vaquita Refuge Area. Fishermen from this port work in the vicinity of the refuge throughout the year. Although El Golfo de Santa Clara has the greatest number of registered permits and small boats, fishermen fish on the northern side of the Vaquita Refuge Area because of the decreased expense of travel to this site. Fishermen from Puerto Peñasco fish near the Sonoran coast to save money on gasoline and oil.

The capture in the Biosphere Reserve and the Vaquita Refuge maintains a steady level of production with important economic incentives, which make it attractive to fishermen despite recent restrictions on their activity. However, the continued recruitment of new fishermen to the area will not enhance the welfare of the existing fishermen and there is no guarantee that the fishery will be sustained over the coming years (Ponce et al. 2006).

When considering whether the marine protected areas in the Upper Gulf of California could succeed as a sustainable environment, social aspects, such as how fishermen embrace their activity, should be considered as well. A buy-out program to restrict fishing in the Vaquita Refuge was established in December 2005. It must be followed by a medium-term plan aimed at finding alternatives to fishing that fishermen consider important to them and the region. Some fishermen would not stop fishing because that is the only activity that they feel comfortable performing and they have done it for years. Each fishery must be individually assessed. The shrimp fishery is known to have a low impact on threatened species mortality in the Vaquita Reserve (D'Agrosa et al. 2000, Rojas et al. 2006). Keeping in mind that each species has an impact on the community structure of their habitat, it is important to regulate the fishing of these species to allow a specific amount of catch using specific fishing methods in the Biosphere Reserve and the Vaquita Refuge.

The conservation of the Vaquita Reserve requires the adoption of strategies that contribute to management and conservation of the ecosystem (Palumbi et al. 2003). Such strategies include considering the fishermen's points of view for the negotiation and legislation processes. It is important to know what fishermen would be willing to accept in return for their agreement to stop fishing in the Vaquita sanctuary. Conservation success, in this case, 
must be based on agreements that dignify the inhabitants of the Upper Gulf of California. These agreements should consider socio-economic, ecological and institutional factors and strive to improve the quality of life for fishermen while helping to preserve the endangered Vaquita Reserve (Davis 2005, Harris et al. 2005, Leslie 2005). The ability of most fishery management policies to conserve species is contingent upon the vulnerability of the species, the size of the protected area and the economic alternatives. Given the critical situation of the Vaquita Reserve, one should question whether the enforcement of the policy designating the refuge as a notake zone will be sufficient to save these species from extinction.

This study was motivated by issues of biodiversity conservation and the opportunity to understand the basic aspects of the Upper Gulf of California fishery. Pressure on the fishery will continue as Mexican authorities reduce the size of the industrial fleets in the zone by buying their fishing permits and vessels, forcing fishermen into smallscale fishing. As a first step towards instituting a monitoring and management strategy for the area, further research will be needed to assess the ecological impacts of small-scale fisheries employing so-called "nondestructive" techniques (Lunn \& Dearden 2006) as a "suriperas nets" in the shrimp fishery (Balmori et al. 2006).

In conclusion, a practical management policy for the fisheries in the marine protected areas is needed to avoid the perception that marine protected areas are only suitable for biodiversity conservation and to address inconsistencies between conservation and fisheries approaches to the regional management of natural resources. Better collaboration and coordination between government agencies and local groups (non-governmental agencies and fishermen) will enhance the fishing programs in the Upper Gulf of California and may help to reduce conflict in the two marine protected areas.

\section{Acknowledgments}

Financial support was provided by CONACYT Grant 48445. GRQ received doctoral studies grants: CONACYT 112401 and COTEPABE-IPN 347. The manuscript benefited from the suggestions of two anonymous reviewers.

\section{Literature cited}

Alfonso P, J Fontes, KN Holland \& R Santos. 2009. Multiscale patterns of habitat use in a highly mobile reef fish, the white trevally Pseudocaranx dentex, and their implications for marine reserve design. Marine Ecology Progress Series 381: 273-286.
Balmori A, JT Silva, E Miranda \& A Rodríguez. 2006. Evaluación de sistemas de captura para una pesca artesanal de camarón eficiente y amigable con el medio ambiente en el Alto Golfo de California, 12 pp. Instituto Nacional de la Pesca-World Wildlife Fundation, Guaymas.

Blanco ML. 2002. Pobreza y explotación de los recursos pesqueros en el Alto Golfo de California. In: Moran-Angulo RE, MT Bravo, S Santos-Guzmán \& JR Ramírez-Zavala (eds). Manejo de los recursos pesqueros, pp. 318-338. Reunión Temática Nacional, Editorial Universidad Autónoma de Sinaloa, Culiacán.

Brusca CR. 2004. The Gulf of California-an overview. In: Brusca CR, E Kimrey \& W Moore (eds). Seashore guide to the northern Gulf of California, pp. 1-8. Arizona-Sonora Museum, Tucson.

Cisneros MMA, G Montemayor \& MJ Román. 1995. Life history and conservation of Totoaba macdonaldi. Conservation Biology 9: 806-814.

Cisneros MMA. 2001. Pesca y manejo pesquero en el Golfo de California. Estudios Sociales 11: 57-69.

Cochran GW. 1989. Sampling techniques, 413 pp. Wiley and Sons, New York.

Cudney R \& PJ Turk. 1998. Pescando entre mareas del Alto Golfo de California, 166 pp. Centro Intercultural de Estudio de Desiertos y Océanos, Puerto Peñasco.

D’Agrosa C, O Vidal \& WC Graham. 1995. Mortality of the Vaquita Phocoena sinus in gillnet fisheries during 19931994. Reports of the International Whaling Commission (Special Issue) 16: 283-291.

D’Agrosa C, CE Lennert-Cody \& O Vidal. 2000. Vaquita by-catch in Mexico's artisanal gillnet fisheries: driving a small population to extinction. Conservation Biology 14: 1110-1119.

Davis GE. 2005. Science and society: marine reserve design for the California Channel Islands. Conservation Biology 19: $1745-1751$.

Galindo BM, EP Glenn, HM Page, K Fitzsimmons, LA Galindo, JM Hernández, RL Petty, J García \& D Moore. 2000. Panaeid shrimp landings in the Upper Gulf of California in relation to Colorado River freshwater discharge. Fishery Bulletin 98(1): 222-225.

Godínez PJA. 1993. Debe vedarse la pesca en el Alto Golfo. Ciclos 9: 13-14.

Greenberg JB. 1993. Local preferences for develop. In: McGuire TR \& JB Greenberg (eds). Marine community and Biosphere Reserve: crises and response in the Upper Gulf of California. Bureau of Applied Research in Anthropology, University of Arizona. Occasional Paper 2: $1-168$

Hanski I. 1998. Metapopulation dynamics. Nature 396: 4149. 
Harris GM, CN Jenkins \& SL Pimm. 2005. Refining biodiversity conservation priorities. Conservation Biology 19: 1957-1968.

Leslie HM. 2005. A synthesis of marine conservation planning approaches. Conservation Biology 19: 1701-1713.

Lunn KE \& P Dearden. 2006. Monitoring small-scale marine fisheries: An example from Thailand's Ko Chang archipelago. Fisheries Research 77: 60-71.

Palumbi SR, SD Gaines, HM Leslie \& RR Warner. 2003. New Wave: high-tech tools to help marine reserve research. Frontiers in Ecology and Environment 1: 73-79.

Pérez-Arvizu EM, AE Aragon-Noriega \& L EspinosaCarreon. 2009. Response of the shrimp population in the Upper Gulf of California to fluctuations in discharges of the Colorado River. Crustaceana 82(5): 615-625.

Ponce DG, F Arreguín \& LF Beltrán. 2006. Indicadores de sustentabilidad y pesca: casos en Baja California Sur, México. In: Beltrán MLF, J Urciaga \& A Ortega (eds). Desarrollo sustentable: ¿Mito o realidad?, pp. 183-221. Centro de Investigaciones Biológicas del Noroeste, S.C, México.

Ramírez RRA \& EAAragón. 2006. Postlarval ecology of the blue shrimp (Litopenaeus stylirostris) and brown shrimp (Farfantepenaeus californiensis) in the Colorado River Estuary. Ciencias Marinas 32: 45-52.

Rojas BL \& A Jaramillo. 2001. Vaquita marina. In: Díaz de León CA \& MA Cisneros (eds). Sustentabilidad y pesca responsable en México. Evaluación y manejo 1999-2000, pp. 897-918. Secretaría de Agricultura, Ganadería, Desarrollo Rural y Alimentación, México.
Rojas BL, RR Reeves \& A Jaramillo. 2006. Conservation of the vaquita Phocoena sinus. Mammal Review 36: 179-216.

Rowell K, KW Flessa, DL Dettman \& M Roman. 2005. The importance of Colorado River Flow to nursery habitats of the Gulf corvine Cynoscion othonopterus. Canadian Journal of Fisheries and Aquatic Sciences 62: 2874-2885.

Rowell K, KW Flessa, DL Dettman, M Roman, LH Gerber \& LT Findley. 2008. Diverting the Colorado River leads to a dramatic life history shift in an endangered marine fish. Biological Conservation 141: 1138-1148.

SAGARPA. 2002. Anuario estadístico de pesca, 266 pp. Instituto Nacional de la Pesca, México.

SEMARNAT. 1995. Programa de manejo. Áreas Naturales Protegidas 1. Reserva de la Biosfera del Alto Golfo de California y Delta del Río Colorado, 76 pp. SEMARNAT/ CONANP, México.

Turk-Boyer PJ. 1989. Assessment of the potential impact of fishing activities in the northern Gulf of California on the Phocoena sinus population, $14 \mathrm{pp}$. Report submitted to the Centre of Marine Conservation, Washington.

Walsh P, S Grant, P Winger, G Blackwood, A BalmoriRamirez \& T Silva-Ramírez. 2004. An investigation of alternative harvesting methods to reduce the by-catch of Vaquita porpoise in the Upper Gulf of California shrimp gillnet fishery, 32 pp. Technical Report, Centre for Sustainable Aquatic Resources and Instituto Nacional de Pesca, México.

Recibido el 02 de junio de 2009 y aceptado el 29 de diciembre de 2009 